\title{
Ulusal veteriner zootekni kongrelerinde sunulan bildirilerin özelliklerinin incelenmesi
}

\author{
Ender Uzabac1 ${ }^{1}$, Mehmet Mustafa Oğan ${ }^{2}$
}

${ }^{1}$ Bursa Uludă̆ Üniversitesi, Veteriner Fakültesi, Biyometri Anabilim Dalı, Bursa/TÜRKIYE

${ }^{2}$ Bursa Uludağ Üniversitesi, Veteriner Fakültesi, Zootekni Anabilim Dalı, Bursa/TÜRKIYY

\section{Anahtar Kelimeler: \\ bildiri \\ kongre \\ veteriner zootekni}

Key Words:

congress

proceeding

veterinary animal science

Gelis Tarihi : 06.02 .2021

Kabul Tarihi : 30.04 .2021

Yayin Tarihi : 31.08 .2021

Makale Kodu : 874936

Sorumlu Yazar:

E. UZABACI

(euzabaci@gmail com)

ORCID

E UZABACI : 0000-0002-9634-0055 MM.OG̈AN : 0000-0002-4046-3291

\begin{abstract}
ÖZ
Bu çalışmanın amacı 2004-2018 yılları arasında düzenlenen Ulusal Veteriner Zootekni Kongrelerinde sunulan ve kongre kitaplarında yer alan tüm bildirilerin ve bildiri özetlerinin çeşitli parametreler açısından incelenmesidir. İncelenen bildiriler yazar sayısı, araştırma türü, sunum yapan araştırmacının cinsiyeti, çalışma konusu, sunum yapan araştırmacının bağlı bulunduğu kurum özellikleri açısından yıllara göre değerlendirilmiştir. Bunun yanında kongrelerde sunulan ve orijinal araştırma niteliği taşıyan (derleme olmayan) bildirilerin özetleri de içerik bakımından incelenmiștir. Elde edilen bulgular frekans (n) ve yüzde değerleri $(\%)$ olarak belirtilmiștir. Elde edilen bulgulara göre sözlü sunumlar bakımından en fazla sunumun 2010 ve 2016 yıllarında, poster sunumlar bakımından ise en fazla sunumun 2014 yılında olduğu belirlenmiştir. Tüm kongrelerde sunulan bildirilerin çoğunlukla iki yazarlı olduğu ve sözlü bildirilerin \%79,89'unun ve poster bildirilerin \%79,91’inin orijinal araştırma niteliğinde olduğu belirlenmiștir. Çalıșma konusu bakımından incelendiğinde sözlü sunumların en çok koyun-keçi yetiştiriciliği ve sslahı $(\% 24,34)$ konusunda yapıldığ ancak poster bildirilerin daha çok kanatlı hayvan yetiştiriciliği $(\% 27,07)$ konusunda yapıldığı belirlenmiştir. İncelenen bildiri özetlerinin içerik bakımından değerlendirilmesi sonucunda bildiri özetlerinin çoğunda araştırmanın amacının ve populasyonun tanımının belirtildiği görülmüştür. Bildiri özetlerinin büyük bir kısmında çalışmada kullanılan denek sayısı açıkça belirtilmiş olup araştırma sonuçlarının ve bu sonuçların temel öneri biçiminde yorumlanarak raporlandığı belirlenmiştir. Sonuç olarak, bundan sonra düzenlenecek veteriner zootekni kongrelerinde daha önce sunulmamış farklı konulara öncelik verilmesi ve bildiri özetlerini hazırlarken biçimsel bütünlük için örnek bir şablonun kullanılması önerilmektedir
\end{abstract}

Investigation the properties of the papers presented in national veterinary animal science congress

\begin{abstract}
The aim of this study is to examine all the papers and abstracts presented in the national veterinary animal science congresses arranged between 2004-2018 and contained in the congress books in terms of various parameters. The examined papers were evaluated by the years in terms of the number of authors, the type of research, the gender of the researcher who made the presentation, the subject of the study, and the institutional characteristics of the presenter. In addition, the abstracts of the papers presented at the congresses that were original research (not reviews) were also examined in terms of content. The findings are presented as frequency (n) and percentage values (\%). According to the findings, it was determined that oral presentations were mostly in 2010 and 2016, poster presentations were in 2014. It was detected that the presentations presented in all congresses were mostly with two authors and $79.89 \%$ of oral presentations and $79.91 \%$ of poster presentations were original research. When examined in terms of the subject of the study, it was detected that oral presentations were mostly made on sheep-goat breeding $(24.34 \%)$, but poster presentations were mostly about poultry breeding $(27.07 \%)$. As a result of the evaluation of the reviewed abstracts in terms of content, it was seen that the purpose of the study and the definition of the population were specified in most of the abstracts. In most of the abstracts, the number of subjects used in the study was clearly stated, and it was determined that the research results were interpreted and reported as a basic recommendation. As a result, it is recommended to give priority to different subjects that have not been presented before in veterinary animal science congress to be arranged from now on and to use a sample template for formal integrity while preparing abstracts.
\end{abstract}

\section{GİRIŞ}

Ulusal Veteriner Zootekni Kongresi ilk kez 2004 y1lında F1rat Üniversitesi Veteriner Fakültesi tarafindan düzenlenmiştir. İkincisi ise 2008 y1linda Erzurum'da gerçekleştirildikten sonra bu tarihten itibaren 2018 y1lına kadar her iki yılda bir Türkiye'nin farklı illerinde ve farklı üniversitelerin veteriner fakülteleri tarafından düzenlenmiştir. 2020 yılında yapılması planlanan kongre ise dünyada ve Türkiye'de yaşanan pandemi (Covid-19) nedeni ile gerçekleştirilememiştir.

Ulusal Veteriner Zootekni Kongrelerinin amac1 Türkiye'de ve dünyada hayvan yetiştiriciliği, hayvan sslahı, hayvan refahı ve genetik alanlarında gerçekleşmekte olan gelişmeleri ortaya koymak ve bilimsel çalışmaları paylaşmaktır. Bu amaç doğrultusunda kongrelerde sığır yetiştiriciliği, koyun ve keçi yetişti- 
riciliği, kanatlı hayvan yetiştiriciliği, at yetiştiriciliği, pet hayvanı yetiştiriciliği, hayvan refahı, biyoistatistik ve genetik gibi konularda yapılmış sözlü ve poster bildiriler sunulmaktadır. Türkiye'de veteriner zootekni alanında çalışan özel işletmelerin yanında, belediyeleri ve üniversiteleri bir araya getirmesi, zootekni alanında yapılan gelişmeleri paylaşması ve sorunların tartışılarak çözüm geliştirilmeye çalışılması bakımından Veteriner Zootekni Kongreleri oldukça önemli bir bilimsel platformdur. Ulusal Veteriner Zootekni Kongreleri, ikincisinin ilkinden dört y1l sonra düzenlenmesi dışında her iki yılda bir düzenlenen periyodik bir toplantı özelliğindedir ve süreli yayın olarak düşünülebilir.

Türkiye'de farklı bilim alanlarında düzenlenen ulusal kongrelerde sunulan bildirilerin bibliyometrik olarak incelendiği çalışmalar mevcuttur (1-5). Veteriner bilimleri bakımından incelendiğinde ise ulusal veteriner anatomi kongrelerinde sunulan bildirilerin incelendiği çalışma (6) dişında bu alanda benzer bir araştırmaya rastlanmamıştır.

Bu çalışmanın amac1 2004-2018 yılları arasında gerçekleştirilen Ulusal Veteriner Zootekni Kongrelerinin kitaplarında yer alan sözlü ve poster olarak sunulan tüm bildirileri belirlenen bazı özellikler bakımından nicel olarak incelemektir. Bunun yanında çalışmada, kongrelerde sunulan bildirilerin içerik özelliklerinin de incelenmesi ve değerlendirilmesi amaçlanmıştır.

\section{GEREÇ ve YÖNTEM}

Bu çalışmada 2004-2018 yılları arasında düzenlenmiş olan Ulusal Veteriner Zootekni Kongrelerinde sunulan ve bildiri kitaplarında yayınlanan tüm (sözlü ve poster) bildiriler kullanılmıştır. Çalışmada, yedi kongrede sunulan 189 sözlü ve 229 poster olmak üzere 418 bildiri incelenmiştir. Belirtilen tarihler arasında düzenlenen tüm kongrelere ait kongre kitaplarına erişim sağlanmıştır. Sunulan bildiriler öncelikle sözlü ve poster sunumlar için ayrı ayrı olmak üzere çeşitli parametreler dikkate alınarak incelenmiştir. Bildirilerin bibliyometrik özelliklerinin ortaya çıkarılabilmesi için sunulan bildiri türü, bildiride yer alan yazar sayısı, bildiriyi sunan araştırmacının cinsiyeti, sunulan çalışmanın konusu ve sunum yapan araştırmacinın bağlı bulunduğu bölüm, anabilim dalı ya da kurum bilgileri incelenmiştir. Bu çalışmada bildirilere ait incelenen özellikler yıllara göre s1nıflandırılarak değerlendirilmiştir.

Buna ek olarak, bildiri kitaplarında yayınlanan bildiri özetleri içerik bakımından incelenmiştir. Bu aşamada ise bildiri özetinde; araştırmanın amacının, araştırmada incelenen populasyo- nun tanımının, örneklem büyüklüğünün, kullanılan örnekleme yönteminin, araştırmanın yapılma zamanının, araştırmanın yapıldığ1 yerin, kullanılan istatistiksel yöntemlerin, bulguların ve araştırmanın sonunda elde edilen sonucun açıç̧a belirtilip belirtilmemesi durumu incelenmiştir. Çalışmada hem bildirilerin genel özellikleri hem de bildiri özetlerinin içeriğine ilişkin incelenen özelliklere ait sayı (n) ve yüzde (\%) değerleri hesaplanmıştır. Bildiri özet içeriğinin incelenmesi aşamasında yalnızca orijinal araştırma niteliğinde olan çalışmalar incelenmiş olup; derleme niteliğindeki sunumlar değerlendirme dişı bırakılmıştir.

\section{BULGULAR}

Ulusal Veteriner Zootekni Kongrelerinin gerçekleştirildiği y1llar ve kongreleri düzenleyen kurumlar hakkındaki bilgi Tablo-1'de yer almaktadir.

Sözlü bildirilere ait özelliklerin y1llara göre dağılımını gösteren bulgular Tablo-2'de yer almaktadır. Söz konusu tabloya göre, en çok sözlü bildirinin 2010 ( $n=37)$ ve 2016 ( $n=38)$ yıllarında sunulduğu belirlenmiştir. Poster bildirilere ait özelliklerin yıllara göre dağılımını gösteren bulgular ise Tablo-3'de yer almaktadır. Yine ilgili tabloya bakıldığında, en çok poster bildirinin (n=60) 2014 yilında sunulduğu görülmüştür.

Düzenlenen tüm kongrelerde sunulan bildirilerin çoğunlukla iki yazarlı olduğu belirlenmiştir. İki yazarlı bildiriler sözlü sunumların \%30,16'sın1; poster bildirilerin ise \%35,37'sini oluşturmaktadır. Kongrelerde sunulan sözlü bildirilerin \%79,89'unu ve poster bildirilerin \%79,91'ini orijinal araştırmalar oluşturmaktadır. Çalışma konusu bakımından incelendiğinde sözlü sunumların en çok koyun-keçi yetiştiriciliği ve ıslahı $(\% 24,34)$ konusunda yapıldı̆̆ 1 ancak poster bildirilerin daha çok kanatlı hayvan yetiştiriciliği $(\% 27,07)$ konusunda yapıldığ1 belirlenmiştir. Kongrelerde sunum yapan araştırmacıların çoğunun erkek ve Veteriner Fakültelerinin Zootekni Anabilim dalında görev yaptığı belirlenmiştir.

Orijinal araştırma niteliği taşıyan (derleme olmayan) bildiri özetlerinin içerik bakımından değerlendirme sonuçları Tablo-4'de yer almaktadır. Elde edilen bulgular bildiri özetlerinin çoğunda araştırma amacının ve çalışma materyalinin tanımının yapıldığını, çalışmada kullanılan denek sayısının belirtildiğini göstermektedir. Ayrıca bulgular, bildiri özetlerinin çoğunda araştırma sonuçlarının ve bu sonuçların temel öneri biçiminde yorumlanarak raporlandığını göstermektedir.

Tablo 1. Ulusal Veteriner Zootekni kongreleri hakkında bilgi

\begin{tabular}{lll}
\hline Kongre & Y1l & Düzenleyen Kurum \\
\hline 1. Ulusal Veteriner Zootekni Kongresi & 2004 & Firat Üniversitesi Veteriner Fakültesi, Elazı̆̆ \\
2. Ulusal Veteriner Zootekni Kongresi & 2008 & Atatürk Üniversitesi Veteriner Fakültesi, Erzurum \\
3. Ulusal Veteriner Zootekni Kongresi & 2010 & Afyon Kocatepe Üniversitesi Veteriner Fakültesi, Afyon \\
4. Ulusal Veteriner Zootekni Kongresi & 2012 & Adnan Menderes Üniversitesi Veteriner Fakültesi, Aydın \\
5. Ulusal Veteriner Zootekni Kongresi & 2014 & Mehmet Akif Ersoy Üniversitesi Veteriner Fakültesi, Burdur \\
6. Ulusal Veteriner Zootekni Kongresi & 2016 & Erciyes Üniversitesi Veteriner Fakültesi, Kayseri \\
7. Ulusal Veteriner Zootekni Kongresi & 2018 & Mustafa Kemal Üniversitesi Veteriner Fakültesi, Hatay \\
\hline
\end{tabular}


Tablo 2. Ulusal Veteriner Zootekni kongrelerinde sunulan sözlü bildirilerin bazı özellikleri

\begin{tabular}{|c|c|c|c|c|c|c|c|c|c|}
\hline & & & & & Yillar & & & & \\
\hline \multirow{10}{*}{ Yazar Sayısı } & & 2004 & 2008 & 2010 & 2012 & 2014 & 2016 & 2018 & Toplam \\
\hline & & $(n=16)$ & $(n=21)$ & $(n=37)$ & $(n=21)$ & $(n=30)$ & $(n=38)$ & $(n=26)$ & \\
\hline & & $\mathrm{n}(\%)$ & $\mathrm{n}(\%)$ & $\mathrm{n}(\%)$ & $\mathrm{n}(\%)$ & $\mathrm{n}(\%)$ & $\mathrm{n}(\%)$ & $\mathrm{n}(\%)$ & $\mathrm{n}(\%)$ \\
\hline & 1 yazarlı & $3(18,75)$ & $1(4,76)$ & $7(18,92)$ & $0(0,00)$ & $1(3,33)$ & $8(21,05)$ & $3(11,54)$ & $23(12,17)$ \\
\hline & 2 yazarlı & $5(31,25)$ & $6(28,57)$ & $14(37,83)$ & $6(28,57)$ & $7(23,33)$ & $10(26,32)$ & $9(34,62)$ & $57(30,16)$ \\
\hline & 3 yazarlı & $1(6,25)$ & $2(9,52)$ & $4(10,81)$ & $5(23,81)$ & $5(16,67)$ & $8(21,05)$ & $4(15,38)$ & $29(15,34)$ \\
\hline & 4 yazarlı & $6(37,50)$ & $1(4,76)$ & $7(18,92)$ & $4(19,04)$ & $9(30,00)$ & $4(10,53)$ & $3(11,54)$ & $34(17,99)$ \\
\hline & 5 yazarlı & $1(6,25)$ & $5(23,81)$ & $3(8,11)$ & $4(19,04)$ & $2(6,67)$ & $3(7,89)$ & $4(15,38)$ & $22(11,64)$ \\
\hline & 6 yazarlı & $0(0,00)$ & $4(19,05)$ & $1(2,70)$ & $2(9,52)$ & $4(13,33)$ & $1(2,63)$ & $2(7,69)$ & $14(7,41)$ \\
\hline & $7 \mathrm{ve}+$ & $0(0,00)$ & $2(9,52)$ & $1(2,70)$ & $0(0,00)$ & $2(6,67)$ & $4(10,53)$ & $1(3,85)$ & $10(5,29)$ \\
\hline \multirow[t]{2}{*}{ Çalışma Türü } & Orijinal çalışma & $11(68,75)$ & $18(85,71)$ & $26(70,27)$ & $20(95,24)$ & $27(90,00)$ & $30(78,95)$ & $19(73,08)$ & $151(79,89)$ \\
\hline & Derleme & $5(31,25)$ & $3(14,29)$ & $11(29,73)$ & $1(4,76)$ & $3(10,00)$ & $8(21,05)$ & $7(26,92)$ & $38(20,11)$ \\
\hline \multirow{9}{*}{$\begin{array}{l}\text { Araştırmanın } \\
\text { Konusu }\end{array}$} & Sığır Yetiş. ve Islahı & $4(25,00)$ & $2(9,52)$ & $10(27,02)$ & $3(14,29)$ & $8(26,67)$ & $7(18,42)$ & $3(11,54)$ & $37(19,58)$ \\
\hline & Koyun-Keçi Yetiş. ve Islahı & $4(25,00)$ & $6(28,57)$ & $7(18,92)$ & $6(28,57)$ & $7(23,33)$ & $11(28,94)$ & $5(19,23)$ & $46(24,34)$ \\
\hline & $\begin{array}{l}\text { Kanatlı Hayvan Yetiş. ve } \\
\text { Islahı }\end{array}$ & $1(6,25)$ & $5(23,81)$ & $5(13,51)$ & $5(23,81)$ & $4(13,33)$ & $4(10,53)$ & $2(7,69)$ & $26(13,76)$ \\
\hline & At Yetiştiriciliği & $1(6,25)$ & $0(0,00)$ & $0(0,00)$ & $1(4,76)$ & $4(13,33)$ & $1(2,63)$ & $1(3,85)$ & $8(4,23)$ \\
\hline & Pet Hayvanı Yetiştiriciliği & $1(6,25)$ & $1(4,76)$ & $2(5,41)$ & $3(14,29)$ & $3(10,00)$ & $0(0,00)$ & $0(0,00)$ & $10(5,29)$ \\
\hline & Hayvan Refahı & $1(6,25)$ & $3(14,29)$ & $5(13,51)$ & $2(9,52)$ & $0(0,00)$ & $2(5,26)$ & $0(0,00)$ & $13(6,88)$ \\
\hline & Genetik & $1(6,25)$ & $3(14,29)$ & $8(21,62)$ & $1(4,76)$ & $0(0,00)$ & $1(2,63)$ & $5(19,23)$ & $19(10,05)$ \\
\hline & Biyoistatistik/Biyometri & $0(0,00)$ & $0(0,00)$ & $0(0,00)$ & $0(0,00)$ & $0(0,00)$ & $2(5,26)$ & $4(15,38)$ & $6(3,17)$ \\
\hline & Diğer/Genel ${ }^{*}$ & $3(18,75)$ & $1(4,76)$ & $0(0,00)$ & $0(0,00)$ & $4(13,33)$ & $10(26,32)$ & $6(23,08)$ & $24(12,70)$ \\
\hline \multirow{3}{*}{$\begin{array}{l}\text { Sunum yapan } \\
\text { araştırmacinın } \\
\text { cinsiyeti }\end{array}$} & Kadin & $0(0,00)$ & $7(33,33)$ & $11(29,73)$ & $3(14,29)$ & $6(20,00)$ & $9(23,68)$ & $8(30,77)$ & $44(23,28)$ \\
\hline & Erkek & $16(100,0)$ & $14(66,67)$ & $26(70,27)$ & $18(85,71)$ & $24(80,00)$ & $29(76,32)$ & $18(69,23)$ & $145(76,72)$ \\
\hline & Zootekni & $16(100,0)$ & $16(76,19)$ & $27(72,97)$ & $15(71,43)$ & $11(36,67)$ & $17(44,74)$ & $13(50,00)$ & $115(60,85)$ \\
\hline \multirow{6}{*}{$\begin{array}{l}\text { Sunum yapan } \\
\text { araştırmacının } \\
\text { bağlı bulun- } \\
\text { duğu bölüm/ } \\
\text { anabilim dalı }\end{array}$} & Genetik & $0(0,00)$ & $3(14,29)$ & $4(10,81)$ & $2(9,52)$ & $9(30,00)$ & $5(13,16)$ & $6(23,08)$ & $29(15,34)$ \\
\hline & Biyoistatistik & $0(0,00)$ & $0(0,00)$ & $2(5,41)$ & $3(14,29)$ & $4(13,33)$ & $4(10,53)$ & $4(15,38)$ & $17(8,99)$ \\
\hline & Hayvan Sağlı̆̆g Ekonomisi & $0(0,00)$ & $1(4,76)$ & $1(2,70)$ & $0(0,00)$ & $3(10,00)$ & $0(0,00)$ & $0(0,00)$ & $5(2,65)$ \\
\hline & Hayvan Besleme & $0(0,00)$ & $0(0,00)$ & $0(0,00)$ & $0(0,00)$ & $0(0,00)$ & $1(2,63)$ & $0(0,00)$ & $1(0,53)$ \\
\hline & Meslek Yüksek Okulu & $0(0,00)$ & $1(4,76)$ & $2(5,41)$ & $1(4,76)$ & $1(3,33)$ & $5(13,16)$ & $2(7,69)$ & $12(6,35)$ \\
\hline & Diğer & $0(0,00)$ & $0(0,00)$ & $1(2,70)$ & $0(0,00)$ & $2(6,67)$ & $6(15,79)$ & $1(3,85)$ & $10(5,29)$ \\
\hline
\end{tabular}

*Tam Güneş Tutulması’nın hayvan davranışları üzerine etkisi, ahırlarda gübre yönetimi ile ilgili karşıllaşılan problemler, hayvancılığın desteklenmesi hakkında uygulama esasları vb.

\section{TARTIŞMA}

Bu çalışmada, Türkiye'de düzenlenmiş yedi Veteriner Zootekni Kongresinde sunulan bildiriler bazı özellikler bakımından incelenmiștir. Daha önce veteriner bilimleri konusunda bu amaçla yapilmış sadece bir çalışma (6) bulunmakta olup; veteriner zootekni alanındaki kongrelerde sunulan bildirilerin incelendiği herhangi bir çalışmaya rastlanmamıştır. Bu çalışma, sunulan bildirilerin bazı özellikler bakımından yıllara göre dağllımını incelerken aynı zamanda yayınlanan bildiri özetlerinin içeriklerinin de değerlendirilmesi nedeni ile kapsamlı bir araştırmadir. 
Tablo 3. Ulusal Veteriner Zootekni kongrelerinde sunulan poster bildirilerin bazı özellikleri

\begin{tabular}{|c|c|c|c|c|c|c|c|c|c|}
\hline & & & & & Yillar & & & & \\
\hline \multirow{10}{*}{ Yazar Sayısı } & & 2004 & 2008 & 2010 & 2012 & 2014 & 2016 & 2018 & Toplam \\
\hline & & $(n=20)$ & $(n=37)$ & $(n=21)$ & $(n=29)$ & $(n=60)$ & $(n=43)$ & $(n=19)$ & \\
\hline & & $\mathrm{n}(\%)$ & $n(\%)$ & $n(\%)$ & $n(\%)$ & $n(\%)$ & $\mathrm{n}(\%)$ & $\mathrm{n}(\%)$ & $n(\%)$ \\
\hline & 1 yazarlı & $0(0,00)$ & $3(8,11)$ & $4(19,05)$ & $3(10,34)$ & $5(8,33)$ & $3(6,98)$ & $3(15,79)$ & $21(9,17)$ \\
\hline & 2 yazarlı & $10(50,00)$ & $18(48,65)$ & $6(28,57)$ & $12(41,38)$ & $14(23,33)$ & $14(32,56)$ & $7(36,84)$ & $81(35,37)$ \\
\hline & 3 yazarlı & $5(25,00)$ & $12(32,43)$ & $4(19,05)$ & $4(13,79)$ & $11(18,33)$ & $10(23,26)$ & $3(15,79)$ & $49(21,40)$ \\
\hline & 4 yazarlı & $4(20,00)$ & $3(8,11)$ & $5(23,81)$ & $7(24,14)$ & $14(23,33)$ & $8(18,60)$ & $2(10,53)$ & $43(18,78)$ \\
\hline & 5 yazarlı & $1(5,00)$ & $1(2,70)$ & $1(4,76)$ & $2(6,90)$ & $4(6,67)$ & $3(6,98)$ & $2(10,53)$ & $14(6,11)$ \\
\hline & 6 yazarlı & $0(0,00)$ & $0(0,00)$ & $0(0,00)$ & $1(3,45)$ & $6(10,00)$ & $2(4,65)$ & $2(10,53)$ & $11(4,80)$ \\
\hline & $7 \mathrm{ve}+$ & $0(0,00)$ & $0(0,00)$ & $1(4,76)$ & $0(0,00)$ & $6(10,00)$ & $3(6,98)$ & $0(0,00)$ & $10(4,37)$ \\
\hline \multirow[t]{2}{*}{ Çalışma Türü } & Orijinal çalışma & $15(75,00)$ & $30(81,08)$ & $21(100,0)$ & $22(75,86)$ & $49(81,67)$ & $34(79,07)$ & $12(63,16)$ & $183(79,91)$ \\
\hline & Derleme & $5(25,00)$ & $7(18,92)$ & $0(0,00)$ & $7(24,14)$ & $11(18,33)$ & $9(20,93)$ & $7(36,84)$ & $46(20,09)$ \\
\hline \multirow{9}{*}{$\begin{array}{l}\text { Araştırmanin } \\
\text { Konusu }\end{array}$} & Sığır Yetiş. ve Islahı & $2(10,00)$ & $8(21,62)$ & $3(14,29)$ & $6(20,69)$ & $12(20,00)$ & $10(23,26)$ & $3(15,79)$ & $44(19,21)$ \\
\hline & Koyun-Keçi Yetiş. ve Islahı & $11(55,00)$ & $7(18,92)$ & $3(14,29)$ & $4(13,79)$ & $12(20,00)$ & $14(32,56)$ & $3(15,79)$ & $54(23,58)$ \\
\hline & $\begin{array}{l}\text { Kanatlı Hayvan Yetiş. ve } \\
\text { Islahı }\end{array}$ & $5(25,00)$ & $14(37,84)$ & $9(42,86)$ & $10(34,48)$ & $15(25,00)$ & $6(13,95)$ & $3(15,79)$ & $62(27,07)$ \\
\hline & At Yetiştiriciliği & $0(0,00)$ & $2(5,41)$ & $1(4,76)$ & $2(6,90)$ & $4(6,67)$ & $0(0,00)$ & $2(10,53)$ & $11(4,80)$ \\
\hline & Pet Hayvanı Yetiştiriciliği & $0(0,00)$ & $0(0,00)$ & $3(14,29)$ & $2(6,90)$ & $2(3,33)$ & $3(6,98)$ & $1(5,26)$ & $11(4,80)$ \\
\hline & Hayvan Refahı & $0(0,00)$ & $1(2,70)$ & $0(0,00)$ & $1(3,45)$ & $0(0,00)$ & $2(4,65)$ & $1(5,26)$ & $5(2,18)$ \\
\hline & Genetik & $0(0,00)$ & $1(2,70)$ & $2(9,52)$ & $0(0,00)$ & $0(0,00)$ & $0(0,00)$ & $1(5,26)$ & $4(1,75)$ \\
\hline & Biyoistatistik/Biyometri & $0(0,00)$ & $0(0,00)$ & $0(0,00)$ & $1(3,45)$ & $0(0,00)$ & $3(6,98)$ & $3(15,79)$ & $7(3,06)$ \\
\hline & Diğer/Genel * & $2(10,00)$ & $4(10,81)$ & $0(0,00)$ & $3(10,34)$ & $15(25,00)$ & $5(11,63)$ & $2(10,53)$ & $31(13,55)$ \\
\hline \multirow{3}{*}{$\begin{array}{l}\text { Sunum yapan } \\
\text { araştırmacının } \\
\text { cinsiyeti }\end{array}$} & Kadın & $1(5,00)$ & $7(18,92)$ & $7(33,33)$ & $12(41,38)$ & $20(33,33)$ & $10(23,26)$ & $6(31,58)$ & $63(27,51)$ \\
\hline & Erkek & $19(95,00)$ & $30(81,08)$ & $14(66,67)$ & $17(58,62)$ & $40(66,67)$ & $33(76,74)$ & $13(68,42)$ & $166(72,49)$ \\
\hline & Zootekni & $18(90,00)$ & $25(67,57)$ & $19(90,48)$ & $23(79,31)$ & $32(53,33)$ & $22(51,16)$ & $12(63,16)$ & $151(65,94)$ \\
\hline \multirow{6}{*}{$\begin{array}{l}\text { Sunum yapan } \\
\text { araştırmacinın } \\
\text { bağlı bulun- } \\
\text { duğu bölüm/ } \\
\text { anabilim dalı }\end{array}$} & Genetik & $0(0,00)$ & $0(0,00)$ & $0(0,00)$ & $1(3,45)$ & $10(16,67)$ & $4(9,30)$ & $1(5,26)$ & $16(6,99)$ \\
\hline & Biyoistatistik & $0(0,00)$ & $0(0,00)$ & $0(0,00)$ & $1(3,45)$ & $7(11,67)$ & $2(4,65)$ & $3(15,79)$ & $13(5,68)$ \\
\hline & Hayvan Sağlığ1 Ekonomisi & $0(0,00)$ & $3(8,11)$ & $0(0,00)$ & $0(0,00)$ & $3(5,00)$ & $1(2,33)$ & $0(0,00)$ & $7(3,06)$ \\
\hline & Hayvan Besleme & $2(10,00)$ & $3(8,11)$ & $1(4,76)$ & $0(0,00)$ & $0(0,00)$ & $0(0,00)$ & $0(0,00)$ & $6(2,62)$ \\
\hline & Meslek Yüksek Okulu & $0(0,00)$ & $5(13,51)$ & $1(4,76)$ & $1(3,45)$ & $4(6,67)$ & $5(11,63)$ & $1(5,26)$ & $17(7,42)$ \\
\hline & Diğger & $0(0,00)$ & $1(2,70)$ & $0(0,00)$ & $3(10,34)$ & $4(6,67)$ & $9(20,93)$ & $2(10,53)$ & $19(8,29)$ \\
\hline
\end{tabular}

*Genel Zootekni terimlerinde anlam birliği, Erzurum ili hayvancıllı̆ı̆ın genel değerlendirmesi, Organik çiftlik hayvanları yetiştiriciliğinin esasları vb.

Düzenlenen ilk Veteriner Zootekni kongresinde toplam otuz altı adet bildirinin sunulduğu belirlenmiştir. Bazı yıllarda sunulan bildiri sayılarının ilk kongrede sunulan bildiri sayıs1nın yaklaşık iki katından daha fazla olduğu görülmektedir. Bu sonuç zamanla bu kongrelere ilginin ve katıllımın arttı̆̆ını göstermektedir. En çok bildirinin sunulduğu kongreler ise 2014
( $n=90)$ ve $2016(n=81)$ y1llarında düzenlenenler olmuştur.

Sunulan sözlü bildirilerde 2004 ve 2014 yıllarında dört yazarlı bildirilerin daha fazla olduğu belirlenmiş; ancak yazar sayllarına göre genel değerlendirme sonucunda, hem sözlü hem de poster olarak en fazla iki yazarlı bildirilerin olduğu tespit edilmiştir. Bunun yanında altı ve daha fazla yazarın yer aldığı 
Tablo 4. Kongrelerde sunulan tüm bildirilerin özet içeriği ile ilgili özellikleri

\begin{tabular}{|c|c|c|c|c|c|c|c|c|c|}
\hline & \multicolumn{9}{|c|}{ Yillar } \\
\hline & & 2004 & 2008 & 2010 & 2012 & 2014 & 2016 & 2018 & Toplam \\
\hline & & $\mathrm{n}(\%)$ & $\mathrm{n}(\%)$ & $\mathrm{n}(\%)$ & $\mathrm{n}(\%)$ & $\mathrm{n}(\%)$ & $\mathrm{n}(\%)$ & $\mathrm{n}(\%)$ & $\mathrm{n}(\%)$ \\
\hline \multirow{2}{*}{$\begin{array}{l}\text { Araştırmanın } \\
\text { amacı }\end{array}$} & Evet & $26(100,00)$ & $40(83,30)$ & $42(89,40)$ & $32(76,20)$ & $69(90,80)$ & $53(82,80)$ & $25(80,60)$ & $287(85,93)$ \\
\hline & Hayır & $0(0,00)$ & $8(16,7)$ & $5(10,60)$ & $10(23,80)$ & $7(9,20)$ & $11(17,20)$ & $6(19,40)$ & $47(14,07)$ \\
\hline \multirow{2}{*}{$\begin{array}{l}\text { Populasyonun } \\
\text { tanimi }\end{array}$} & Evet & $24(92,30)$ & $47(97,90)$ & $45(95,70)$ & $40(95,20)$ & $73(96,10)$ & $59(92,20)$ & $29(93,50)$ & $317(94,91)$ \\
\hline & Hayır & $2(7,70)$ & $1(2,10)$ & $2(4,30)$ & $2(4,80)$ & $3(3,90)$ & $5(7,80)$ & $2(6,50)$ & $17(5,09)$ \\
\hline \multirow{2}{*}{$\begin{array}{l}\text { Örneklem } \\
\text { büyüklüğ̈̈ü }\end{array}$} & Evet & $22(84,60)$ & $37(77,10)$ & $42(89,40)$ & $41(97,60)$ & $66(86,80)$ & $51(79,70)$ & $28(90,30)$ & $287(85,93)$ \\
\hline & Hayır & $4(15,4)$ & $11(22,90)$ & $5(10,60)$ & $1(2,40)$ & $10(13,20)$ & $13(20,30)$ & $3(9,70)$ & $47(14,07)$ \\
\hline \multirow{2}{*}{$\begin{array}{l}\text { Örnekleme } \\
\text { yöntemi }\end{array}$} & Evet & $0(0,00)$ & $0(0,00)$ & $0(0,00)$ & $0(0,00)$ & $1(1,30)$ & $2(3,10)$ & $0(0,00)$ & $3(0,90)$ \\
\hline & Hayır & $26(100,00)$ & $48(100,00)$ & $47(100,00)$ & $42(100,00)$ & $75(98,70)$ & $62(96,90)$ & $31(100,00)$ & $331(99,10)$ \\
\hline \multirow{2}{*}{$\begin{array}{l}\text { Araştırmanın } \\
\text { zamanı }\end{array}$} & Evet & $4(15,40)$ & $9(18,80)$ & $8(17,00)$ & $8(19,00)$ & $21(27,60)$ & $17(26,60)$ & $7(22,60)$ & $74(22,16)$ \\
\hline & Hayır & $22(84,60)$ & $39(81,30)$ & $39(83,00)$ & $34(81,00)$ & $55(72,40)$ & $47(73,40)$ & $24(77,40)$ & $260(77,84)$ \\
\hline \multirow{2}{*}{$\begin{array}{l}\text { Araştırmanın } \\
\text { yapıldığı yer }\end{array}$} & Evet & $10(38,50)$ & $20(41,70)$ & $17(36,20)$ & $11(26,20)$ & $29(38,20)$ & $27(42,20)$ & $14(45,20)$ & $128(38,32)$ \\
\hline & Hayır & $16(61,50)$ & $28(58,30)$ & $30(63,80)$ & $31(73,80)$ & $47(61,80)$ & $37(57,80)$ & $17(54,80)$ & $206(61,68)$ \\
\hline \multirow{2}{*}{$\begin{array}{l}\text { Kullanılan istatis- } \\
\text { tiksel yöntem }\end{array}$} & Evet & $8(30,80)$ & $17(35,40)$ & $9(19,10)$ & $7(16,70)$ & $17(22,40)$ & $12(18,80)$ & $11(36,70)$ & $81(24,25)$ \\
\hline & Hayır & $18(69,20)$ & $31(64,60)$ & $38(80,90)$ & $35(83,30)$ & $59(77,60)$ & $52(81,30)$ & $19(63,30)$ & $253(75,75)$ \\
\hline \multirow{2}{*}{$\begin{array}{l}\text { Ana bulguların } \\
\text { raporlanması }\end{array}$} & Evet & $22(84,60)$ & $43(89,60)$ & $41(87,20)$ & $36(85,70)$ & $65(85,50)$ & $51(79,70)$ & $27(87,10)$ & $285(85,33)$ \\
\hline & Hayır & $4(15,40)$ & $5(10,40)$ & $6(12,80)$ & $6(14,30)$ & $11(14,50)$ & $13(20,30)$ & $4(12,90)$ & $49(14,67)$ \\
\hline \multirow{2}{*}{$\begin{array}{l}\text { Temel önerinin } \\
\text { belirtilmesi }\end{array}$} & Evet & $19(73,10)$ & $37(77,10)$ & $36(76,60)$ & $33(78,60)$ & $73(96,10)$ & $55(85,90)$ & $26(83,90)$ & $279(83,53)$ \\
\hline & Haylr & $7(26,90)$ & $11(22,90)$ & $11(23,40)$ & $9(21,40)$ & $3(3,90)$ & $9(14,10)$ & $5(16,10)$ & $55(16,47)$ \\
\hline
\end{tabular}

bildirilerin sayısının ise oldukça az olduğu belirlenmiştir. Sunulan araştırmaların türü incelendiğinde elde edilen sonuçlar düzenlenen tüm kongrelerde orijinal çalışmaların oranının daha yüksek olduğunu göstermektedir. Bu oran sözlü $(\% 79,89)$ ve poster bildirilerde $(\% 79,91)$ birbirine çok yakın olarak belirlenmiştir. Bu sonuç; hem sözlü hem poster bildirilerde yeni ve özgün çalışmaların sayısının literatürde mevcut bilgilerin bir araya getirildiği derleme niteliğindeki çalışmalardan daha fazla olduğunu göstermektedir.

Sunulan sözlü bildirilerde 2010 ve 2014 yıllarında sığır yetiştiriciliği ve sslahı konusunda daha fazla bildiri sunulmuș olmasına karşılık; sözlü bildirilerde genel sonuca bakıldığında daha çok koyun-keçi yetiştiriciliği ve sslahı konusunda $(\% 24,34)$ yapılan çalışmaların yer aldığı belirlenmiştir. Bu oranı sığır yetiștiriciliği ve 1slahı $(\% 19,58)$ ile kanatlı hayvan yetiştiriciliği ve ıslahı $(\% 13,76)$ konularında yapılan çalışmalar takip etmektedir. Bu siralamanın 2016 ve 2018 yıllarinda yapilan kongre- lerde aynı olduğu belirlenmiștir. Son iki kongrede pet hayvanı konusunda ve 2016 yllına kadar düzenlenmiş tüm Veteriner Zootekni Kongrelerinde biyoistatistik konusunda sözlü bildiri sunulmamıştır. Bu kongrelerde özellikle biyoistatistik alanında çalışmaların yer almaması önemli bir eksiklik olarak düşünülebilir. Hayvan refahı ve genetik de bazı kongrelerde hiç sunumun yapılmadığı diğer araştırma konularıdır. Poster bildirilerin konularına bakıldığında genel olarak kanatlı hayvan yetiştiriciliği ve ıslahı konusunda çalışmaların daha çok yer aldığı görülmektedir. 2004 ve 2016 yıllarında düzenlenen kongrelerde koyun-keçi yetiştiriciliği ve ıslahı konusunda yapılan çalıșmaların sayısının daha çok olduğu belirlenmiştir. Bazı kongrelerde at yetiştiriciliği, pet hayvanı yetiştiriciliği, hayvan refahı, genetik ve biyoistatistik konularında hiç poster sunumun yapılmadığı da önemli sonuçlardandır. Kongre konularının incelenmesi aşamasında zootekni terimlerinde anlam birliği, bazı illere göre hayvancıllğın genel değerlendirilmesi ve ahırlarda gübre yönte- 
mi gibi konular diğer/genel konu türü olarak sınıflandırılmıştır.

Sunum yapan araştırmacıların cinsiyetleri incelendiğinde daha çok erkek araştırmacıların sunum yaptığı bunun yanında sözlü bildirilerde en çok 2010 yllında 11 çalışmanın, poster bildirilerde ise en çok 2014 yılında 20 çalışmanın kadın araştırmacılar tarafindan sunulduğu tespit edilmiştir.

Bildirileri sunan araştırmacıların çalıştığ1 birimler incelendiğinde daha çok Veteriner Fakültelerinin Zootekni Anabilim dalında görevli akademisyenlerin olduğu; bunun dışında, düzenlenen bu kongrelere Zootekni ve Hayvan Besleme Bölümünün altında yer alan Genetik, Biyoistatistik, Hayvan Sağlığ1 Ekonomisi ve İşletmeciliği ve Hayvan Besleme ve Beslenme Hastalıkları anabilim dallarından da katılımların olduğu belirlenmiştir. Ayrıca çok az da olsa hayvancılık alanı ile ilgili bölümlerin yer aldığ1 meslek yüksekokullarında ve özel kurumlarda (özel köpek eğitim merkezleri gibi) çalışan araştırmacıların da bu kongrelerde sunum yaptığ1 tespit edilmiştir.

Kongrelerde sunulan orjinal araştırma niteliği taşıyan sözlü ve poster bildiriler içerik olarak değerlendirildiğinde; sunulan bildirilerin çoğunda araştırmanın amacının $(\% 85,93)$, araştırmanın hangi materyal ile yapıldığının $(\% 94,91)$ ve araştırmada kullanılan örneklem büyüklüğünün belirtildiği $(\% 85,93)$ tespit edilmiştir. Araştırmada kullanılan örneklemin belirlenmesinde kullanılan örnekleme yönteminin belirtildiği sadece üç çalışma bulunmaktadır. Bu üç çalışmanın ikisinde basit rasgele örneklemeden birinde ise tabakalı örneklemeden yararlanarak örneklemin belirlendiği ifade edilmiştir. İncelenen bildiri özetlerinin \%99,10'unda kullanılan örnekleme yöntemi raporlanmamıştır. Çalışmalarda genellikle verilerin analizi için kullanılan yöntemler açıkça belirtilirken, kullanılan örnekleme yöntemi belirtilmemektedir. Bu bilginin bildiri özetinde yer almaması araştırmac1nın örneklemi belirlerken bir yöntem kullanmamış olmasından ya da özette yer alan kelime sayısı sınırlamasından kaynaklanabilmektedir. Araștırmanın zamanı ve araștırmanın yapıldı̆̆ı yer açısından incelendiğinde bildirilerde bu bilgilerin yer aldığı çalışmaların sayısı oldukça azdır. Bildiri içerikleri kullanılan istatistiksel yöntemin belirtilmesi bakımından değerlendirildiğinde kullanılan yöntemin açık bir şekilde belirtilen bildirilerin oranı \%24,25'dir. Kullanılan yöntem hakkında bilgi içeren çalışmalar incelendiğinde en çok genelleştirilmiş doğrusal modeller, en küçük kareler yöntemi ve ki-kare yöntemlerinin kullanıldığı belirlenmiştir. Çalıșmanın sonucunda elde edilen bulguların açık bir şekilde raporlandığı bildirilerin oranı \% 85,33'tür. Bulguların raporlanması özelliŭgi, çalışmalardan elde edilen sonuçların sayı, yüzde veya tanımlayıcı istatistikler olarak belirtilmesi ayrıca p değerlerinin yazılması olarak değerlendirilmiştir (7). Bildiri özetlerinde genelde son cümle olarak yazılan, araștırmanın bulgularına dayanarak bir temel öneri niteliğinde sonuç cümlesi yer almaktadır. Bildiri özetleri bu açıdan değerlendirildiğinde, sunulan bildirilerin $\% 83,53$ 'ünde sonuç ya da temel öneri cümlesinin yer aldığ belirlenmiştir.

Literatürde yer alan ve kongrelerde sunulan bildirilerin değerlendirildiği çalışmalardan biri olan Melekoğlu ve ark. (8) çalışmasında katılımcıların türü, sayısı ve yaşlarının yanında sunulan bildirinin konusu ve kullanılan araştırma deseni incelenmiştir. Çapık ve ark. (9) ise çalışmasında, çalışmamıza benzer olarak kongrelerde sunulan bildirileri bildiri türü, yazar sayısı ve yazar cinsiyetleri bakımından değerlendirmişlerdir. Yine aynı çalışmada, sadece bir kongrede sunulan bildirilerin incelenmesi nedeniyle çalışmamıza göre daha kısıtlı veriler içermektedir. Bunun yanında Tok Çekmecelioğlu ve ark. (3) ile Çapık ve ark. (9)'nın çalışmalarında, çalışmamızdan farklı olarak kongrede sunulan bildirilerin kongreden sonra çeşitli dergilerde yayımlanma durumları da incelenmiştir. Bu araştırmaların dışında, kongrelerde sunulan bildirilerin incelendiği başka çalışmalarda bildirilere ait özelliklerden yazar sayısı, yazarların ünvanları, kongreye katılım sağlayan üniversiteler ve çalışma türüne göre dağılımlar incelenmiştir $(9,10)$. Çakıcı ve ark. (11) ise bildirilerin özet içeriklerini çalışmamıza benzer olarak detaylı bir şekilde değerlendirmişlerdir. Araştırmanın amacının, kullanılan örnekleme yönteminin, istatistiksel yöntemin belirtilmesi, araştırma zamanı ve ana bulguların raporlanması bakımından incelendiğinde Çakıcı ve ark. nın (11) çalışmasındaki oranlar bu çalışmada bulduğumuz oranlara yakındır. Buna karşılık, aynı çalışmada bildirilerin \%65,2'sinde populasyonun tanımının yapıldığ1 belirtilirken, çalışmamızda bu oran oldukça yüksek bulunmuştur $(\% 94,91)$. Diğer önemli sonuç ise incelenen bildirilerin \%38,32'sinde araştırmanın yeri belirtilmişken; bu oran Çakıcı ve ark. (11) çalışmasında neredeyse iki katına yakın bir değer olarak bulunmuştur $(\% 71,5)$. Benzer şekilde dikkat çekici diğer bir sonuç ise temel önerinin raporlanması ile ilgilidir. Bu çalışmada bildirilerin \%83,53'ünde özetin sonunda sonuç ya da öneri cümlesi yer alırken, Yılmaz (10)'ın çalışmasında bu oranın \%6,3 olduğu belirtilmiştir. Bu farklılık, bildiri özetlerinin kabulü aşamasında özetin içeriğinin nasıl oluşturulacağına dair net bir şablonun yer almamasından kaynaklanabilir.

Bu çalışma kapsamında vurgulanmak istenen özelliklerden bir diğeri bildiri özetlerinde veri analiz yöntemlerinin belirtilmesi durumudur. Aslan ve Özkubat (2) inceledikleri bildiri özetlerinin \%49,1 inde kullanılan yöntemlerin yer almadı̆̆ını belirtirken, yöntemlerin açıkça belirtildiği çalışmalarda kullanılan metotlar ile ilgili bulguları ayrıntılı bir şekilde belirtmişlerdir.

Herhangi bir bilim dalıyla ilgili bilimsel çalışmaların nicelik ve nitelik olarak belirli dönemlerde değerlendirilmesi o bilim dalındaki gelişmelerin incelenmesine olanak sağlamaktadır (12). Bu çalışma ile Veteriner Zootekni Kongrelerinde sunulan bildiriler pek çok özellik bakımından kapsamlı olarak değerlendirilmiş, yöntem ve içerik bakımından bundan sonraki çalışmalara yön verecek bir araştırmanın ortaya konması planlanmıştır. Bu çalışmanın sonuçları konu bakımından incelendiğinde elde edilen en çarpıcı sonuçlardan biri son yıllarda genetik ve biyoistatistik/biyometri konularına ilginin artması ve bu alanda yap1lan çalışmalardaki artıştır. Bununla birlikte; bazı konularda çok fazla çalışma yapılmış olmasına karşılık bazı konularda hiçbir araştırmanın yer almadığı belirlenmiştir. Buna ek olarak bazı çalışmaların ise birbirine çok benzer konularda olduğu görülmüştür. Bundan sonra düzenlenecek kongrelerde bu durumu değiştirebilmek amacıyla güncel ve farklı konuların belirlenmesi ve daha önce yapılmış çalıșmalara benzer çalıșmaların kabul edilmemesi önerilmektedir. Bunun yanında bu çalışmadan elde edilen bulgulardan yola çıkarak bazı konularda yapılacak sunumların teşvik edilmesi ve sadece akademisyenlerin değil lisansüstü eğitim aşamasında olan öğrencilerin de güncel konularla bu kongrelere katılımı desteklenmelidir. 
Özetlerin incelenmesi sonucunda bildirilerin belirli standartlarda yazılmadı̆̆ı, çalışma ile ilgili önemli bilgilerin raporlanmadığı ya da eksik raporlandığı ve bildiri özetlerinin biçimsel bütünlüğünün olmadığ1 belirlenmiştir. Bundan sonra düzenlenecek kongrelerde bildiri özeti gönderimi aşamasında yazımla ilgili bir şablonun oluşturulması ve özetlerin bu şablona göre yazılması zorunluluğunun getirilmesi önerilmektedir.

\section{SONUÇ}

Sonuç olarak, bu çalışmada 2004-2018 y1lları arasında düzenlenmiş olan Veteriner Zootekni Kongrelerinde sunulmuş olan bildiriler çeşitli özellikler bakımından incelenmiştir. Elde edilen sonuçlara dayanarak bu çalışmanın bundan sonra düzenlenecek kongreler için önemli bir rehber ve veri kaynağ1 olacağ1 düşüncesindeyiz.

\section{BEYANNAMELER}

\section{Etik Onay1}

Uygulanamaz.

\section{Çıkar Çatışması}

Yazarlar, herhangi bir çıkar çatışması beyan etmemektedir.

\section{Yazar Katk1ları}

Fikir, Kavram ve Tasarım: E. Uzabacı

Veri Toplama ve Analiz: E. Uzabac1

Makalenin Yazımı: E. Uzabac1, MM. Oğan

Eleştirel İnceleme: MM. Oğan

\section{Veri kullanılabilirliği}

$\mathrm{Bu}$ çalışmanın bulgularını destekleyen veriler makul talep üzerine sorumlu yazardan temin edilebilir.

\section{KAYNAKLAR}

1. Öztürk-Dönmez R, Bayık-Temel A. Türkiye'de hemşirelik ögrrencileri kongrelerinde sunulan bildiri özellikleri (2000-2011). Hemşirelikte Araştırma Geliştirme Dergisi 2014; 16(1): 23-33.

2. Aslan C, Özkubat U. Ulusal özel eğitim kongresi bildirilerindeki araştırma eğilimleri: Bir içerik analizi. Türkiye Sosyal Araştırmalar Dergisi 2019; 23(2): 535-554.

3. Tok Çekmecelioğlu B, Kozanhan B, Eren G. Türk Anesteziyoloji ve Reanimasyon Derneği Ulusal Kongreleri’ndeki Sözel Bildirilerin Yayımlanma Oranı. Turk J Anaesthesiol Reanim. 2019; 47(2): 151-157.

4. Koyuncu MS, Şata M, Karakaya İ. Eğitimde Ölçme ve Değerlendirme Kongrelerinde Sunulan Bildirilerin Doküman Analizi Yöntemi ile Incelenmesi. Eğitimde ve Psikolojide Ölçme ve Değerlendirme Dergisi 2018; 9(2): 216-238.

5. Şahin M, Koç U. Türkiye'deki bilgi yönetimiyle ilgili çalışmalar: bilgi, ekonomi ve yönetim kongre bildirilerinin incelenmesi. Bilgi Ekonomisi ve Yönetim Dergisi 2009; 4(1): 95-112.

6. Dilek ÖG, Demiraslan Y, Gürbüz İ. Türkiye'de ulusal veteriner anatomi kongrelerinde sunulan bildiriler: bir eğilim analizi. MAE Vet Fak Derg. 2019; 4(2): 84-89.

7. Gastel B, Day RA. Bilimsel bir makale nasıl yazılır ve yayımlanır? Gazi Kitabevi 2019.

8. Melekoğlu MA, Sönmez-Kartal M, Melekoğlu M, Genç-Tosun D, Orum-Çattık E, Tunç-Paftalı A, et al. Geçmişten günümüze Türkiye'de özel eğitim kongrelerinde sunulan bildirilerin incelenmesi. 28. Ulusal özel Eğitim Kongresi Kitab1 2018; 1-7.

9. Çapık C, Aydın MA, Gözüm S. I. Ulusal Halk Sağlığ1 Hemşireliği Kongre Bildirilerinin Analizi ve Yayımlanma Oranları. Halk Sağlı̆̆1 Hemşireliği Dergisi 2019; 1(1): 11-27.

10. Yilmaz G. Ulusal turizm kongrelerinde gastronomi ve mutfak sanatları alanı ile ilgili yayınlanan bildiriler üzerine bir araştırma. Turizm ve Araştırma Dergisi 2017; 6(1): 24-39.

11. Çakıcı C, Yıldırım O, Karacaoğlu S. Ulusal Turizm Kongreleri Bildirilerinin Bibliyometrik Profili. 14. Ulusal Turizm Kongresi Bildiriler Kitab1 2013; 1429-1447.

12. Kozak N. Türkiye'de turizm pazarlaması literatürünün gelişim süreci: 1972-1999 yılları arasında hazırlanmış lisansüstü tez çalışmaları üzerine biyo-bibliyografik bir inceleme. Anatolia: Turizm Araştırmaları Dergisi 2001; 12(1): 26-33. 